Eixo Roda, Belo Horizonte, v. 28, n. 3, p. 261-265, 2019

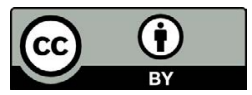

\title{
FREDERICO, Celso. Ensaios sobre Marxismo e Cultura. Rio de Janeiro, Mórula, 2016.
}

Maurício Silva

Universidade Nove de Junho (Uninove), São Paulo, São Paulo / Brasil maurisil@gmail.com

Conhecido por sua extensa e rigorosa obra acerca da economia e da sociedade burguesas, Marx foi também um assíduo leitor de textos literários, não poucas vezes transformando sua leitura em acuradas reflexões acerca da arte em geral e da literatura em particular. Não por outra razão, o célebre pensador alemão tem sido, cada vez mais, abordado como um estudioso dos fenômenos culturais, que, em sua obra, surgem quase sempre vinculados à vida social e material.

É o que procura demonstrar Celso Frederico nos seus Ensaios sobre Marxismo e Cultura, em que trata, entre outras coisas, da relação entre Marx e os marxistas e a literatura, tema presente em vários escritos do autor de $O$ Capital, fazendo parte integrante de sua teoria.

Segundo Celso Frederico, a literatura foi tema de apaixonados debates nos períodos imediatamente anterior e posterior à Revolução Russa de 1917, destacando-se, então, três correntes artísticas: a proletkcult, que via a arte como reflexo dos interesses de uma determinada classe social, incentivando a produção de uma cultura proletária; o grupo produtivista (posteriormente chamado de construtivista), que defendia a arte como uma atividade coletiva e socialmente útil; o futurismo, representado principalmente por Maiakóvski, que defendia uma ruptura estética, em termos de linguagem e forma poética. Apesar de Lênin e Trotsky discordarem de Maiakóvski, não o censuravam, nem acatavam cegamente as premissas da proletkcult. A repressão a algumas dessas correntes viria, contudo, a partir de 1932, com a fundação da União 
dos Escritores Soviéticos, e, em 1934, com o Congresso dos Escritores Soviéticos, encabeçado por Zhdanov e impondo o "realismo socialista" como arte oficial, o que fazia da literatura "mera propaganda da ordem social" (p. 20).

Essas diretrizes não foram, evidentemente, seguidas por todos os teóricos e artistas marxistas. Brecht, por exemplo, cria uma nova forma de realismo no teatro, que abandona a psicologia da personagem e o individualismo em favor da coletividade, colocando em primeiro plano o sujeito coletivo e substituindo a catarse pela reflexão:

Para Brecht, a arte, ao contrário do realismo clássico, não deveria refletir a realidade como um dado fixo e imutável, mas mostrar que as personagens e as ações encenadas são como aparecem porque foram produzidas historicamente e, como tal, podem ser modificadas (p. 22, grifo do autor).

Bakhtin, igualmente, sobreviveu aos expurgos stalinistas, trazendo para os estudos da linguagem a oposição indivíduo-sociedade, valorizando assim - ao contrário de Saussure - o uso que os falantes fazem da linguagem, vista como uma atividade social e ideológica, o que pressupõe uma valorização tanto da enunciação (interação entre os falantes) quanto do dialogismo. Gramsci, por sua vez, entrelaça a reflexão política com questões culturais, num projeto político-cultural que defende uma nova cultura, que reconcilie artistas e povo e que aborde a literatura a partir de uma preocupação educacional:

A proposta do "nacional-popular" era [...] o núcleo da política cultural defendida por Gramsci. A literatura e as questões estéticas são vistas a partir dessa preocupação educacional, desse desejo de elevar a consciência das massas. Desse modo, o que interessa verdadeiramente ao revolucionário sardo é o valor cultural e não apenas o valor estético da obra literária (p. 29, grifos do autor).

Finalmente, Benjamin inaugura, dentro do marxismo, uma corrente que privilegia a fragmentação, recusando o primado da totalidade:

Um ponto de partida que nos ajuda a entender o pensamento de Benjamin é a constatação - que partilhava com Brecht - da crise da experiência $\mathrm{e}$, com ela, a crise da narração, esteio do romance clássico. A consciência dessa crise, própria da modernidade, produziu o romance moderno (Proust, Kafka), que, à semelhança 
da antiga arte de narrar dos contadores de história, se caracteriza pela fragmentação, pelo não acabamento, privilegiando o caráter aberto, recusando-se à totalização (p. 31, grifos do autor).

Muitos teóricos marxistas que escreveram sobre o papel da arte em nossa sociedade, lembra Celso Frederico, tiveram Lukács como referência, cujo pensamento vai da influência kantiana ( $A$ alma e as formas), passando pela incorporação de teses hegelianas (A teoria do romance) até chegar, num registro marxista, à visão do homem como ser social situado numa sociedade de classes (Problemas do realismo). Suas teorias inspiraram autores como Adorno, cujas teorias são apenas em parte de inspiração marxista, e Goldmann, que aborda a literatura a partir da teoria do estruturalismo-genético.

Parte das considerações que Marx fizera acerca da arte pode ser depreendida de seus Manuscritos econômico-filosóficos, obra que marca, no percurso do pensamento marxista, um retorno às questões estéticas, sob a influência de Hegel e Feuerbach: para aquele, a arte surge como o primeiro momento da afirmação do Espírito Absoluto, espécie de alienação do pensamento, a ser superada pela religião e pela filosofia, todas elas buscando, essencialmente, a verdade; para este, contestador do caráter teológico e especulativo de Hegel, a arte revela uma verdade imediata e humana, sendo, por isso, manifestação do ser humano verdadeiro e expressando a "consciência humana do infinito" (p. 54). Segundo Celso Frederico, foi exatamente o caráter antropomorfizador deste último - marcado pelo primado das sensações e pela defesa do humanismo - que atraiu Marx, levando-o a formular suas primeiras teorias estéticas, por meio do materialismo.

Assim, para o jovem Marx, a arte ocuparia um lugar específico em sua nova teoria, já que era entendida como um desdobramento do trabalho, embora possua uma especificidade, sobretudo com a valorização dos sentidos como meio de afirmação do homem. Desse modo, a arte se ligaria ao "processo de formação da humanidade" (p. 67), longe de ser pura contemplação da realidade. Contudo, Marx se opõe, na essência de seu pensamento sobre a arte, tanto a Hegel (a arte não seria manifestação do Espírito, mas criação material do homem) quanto a Feuerbach (a beleza não residiria nos objetos ou na natureza, mas é resultado da atividade humana), defendendo, no final das contas, a arte como práxis: 
Arte não é observação desinteressada das estrelas vagando pelo firmamento e nem contemplação deslumbrada da essência humana em toda parte vista e reconhecida pelo olhar amoroso de um homem eternamente apaixonado. Como atividade prática, a arte é um momento decisivo do processo de autoformação do gênero, de apropriação da realidade e de doação de sentido. Não há lugar para o belo natural no pensamento marxiano. A realidade humana, criada e ampliada pelo trabalho, pela arte e pelas demais objetivações, exige do artista algo mais do que a reprodução mecânica das "aparências amigáveis" do mundo exterior (p. 73, grifo do autor).

E, completando: “A capacidade humana de criar não é um artifício do Espírito que se dá a conhecer por meio de seu aparecimento sensível. Arte, para Marx, é atividade, é forma humana de objetivação que não se deixa superar por outras formas de objetivação" (p. 75).

Celso Frederico dedica especial atenção ao legado teórico do pensador franco-romeno Lucien Goldmann: discorrendo sobre sua Sociologia da Literatura, lembra que, para Goldmann, a literatura é um campo privilegiado de aplicação do estruturalismo-genético (expressão que substitui o conceito de materialismo histórico). Partindo de Lukács ( $A$ alma e as formas e Teoria do romance), Goldmann rejeitaria, assim, a ideia da literatura como reflexo da sociedade, buscando uma nova correlação entre literatura e sociedade, em que as estruturas do universo da obra são homólogas às estruturas mentais de determinados grupos sociais: os grupos sociais estruturam uma resposta consciente às questões do mundo circundante, coerência (visão de mundo) essa que atinge o máximo de articulação na atividade imaginativa do escritor; a arte, assim, favorece a tomada de consciência do grupo social a que pertence, explicando a estrutura significativa que esse grupo elaborou de forma rudimentar; é exatamente o estudo destas estruturas significativas presentes nos grupos sociais o objeto da Sociologia da Literatura. Baseando-se em Lukács e Girard, Goldmann estuda o romance como gênero problemático da classe burguesa, em que o herói se debate na tarefa de buscar valores autênticos num mundo que lhe é hostil: "O romance, produto do mundo burguês, mantém uma relação de 'rigorosa homologia' com as principais fases da estrutura econômica dessa formação social” (p. 88).

Tratando ainda da ideia de criação cultural em Goldmann, o autor expõe sua proposta de uma sociologia da cultura, criada numa perspectiva 
contrária ao existencialismo, por um lado, e ao estruturalismo, por outro. Assim, para Goldmann, numa obra de arte quem fala é sempre a classe social a que pertence o autor (trata-se do sujeito transindividual), além de a obra de arte possuir uma estrutura significativa, isto é, marcada pela historicidade e pela ação humana. Rompendo a tradicional divisão entre uma análise imanente (centrada na compreensão do texto) e uma análise transcendente (centrada em sua explicação), Goldmann propõe um método em que ambas, compreensão e explicação, estejam organicamente concatenadas.

Finalmente, Celso Frederico trata ainda, sempre na perspectiva marxista, da contribuição de Brecht para a teoria do rádio, em especial a reflexão que o dramaturgo alemão fazia acerca do movimento das rádios operárias; das divergências metodológicas entre Adorno e Lazarsfeld, ainda em torno da audição radiofônica; do conceito de sociedade do espetáculo, de Guy Debord; e da cultura e da política em tempos pósmodernos, com destaque para a cultura produzida na periferia.

Recebido em: 28 de novembro de 2018. Aprovado em: 7 de janeiro de 2019. 